\title{
EXPLANATION OF PLATE
}

Outlines (from camera-lucida drawings) of head, prothorax, and elytra of

Fig. 1.-Tachys (s. s.) dominicanus n. sp.

Fig. 2.-Limnastis americanus n. sp.

Fig. 3.-Micratopus parviceps n. sp.

Fig. 4.-Perileptus columbus n. sp.

Fig. 5.-Coptia sauricollis n. sp.

Fig. 6.-Coptia effeminata n. sp.

Fig. 7.-Colpodes macer n. sp.

Fig. 8.-Perigona microps n. sp.

Fig. 9.-Masoreus (Aephnidius) ciliatus n. sp. (Mutchler.)

Fig. 10.-Phloeoxena imitatrix n. sp.

Fig. 11.-Colliuris (Pseudocasnonia) noah n. sp.

Fig. 12.-Pseudaptinus (Thalpius) deceptor n. sp.

\section{SUPPLEMENT:}

Masoreus (Aephnidius) ciliatus new species (Mutchler) (Pl. 5, fig. 9)

Oblong oval, black, legs, antennæ and mouth parts testaceous. Head subquadrate, finely closely punctate; mandibles without setigerous punctures in the scrobes, sides elevated; basal joint of antennæ with a long bristle at apex; front of labrum slightly curved inwardly (almost straight) margin with setigerous punctures; clypeus with a puncture on each side. Pronotum subquadrate, one-third wider than long, wider than the head, widest at about the middle, apical angles narrowly rounded and slightly produced, lateral margin with a setigerous puncture on the apical third and another at the basal fifth, basal angles broadly rounded, marginal bead extending from the side of the insertion of the head to the scutellar area, a median longitudinal impressed line, somewhat well marked, extending from the apex to near the base, with indistinct oblique lines, extending backwards from this median line. Scutellum triangular, apex narrowly rounded. Elytra with humeral angles rounded margins not interrupted, surface (under high 
power magnification) with indications of faint striæ and appearing as if covered with fine scales giving them a silky appearance, possibly granulate punctate, submargin with setigerous punctures, apical angles rounded. Front tibiæ with two elongate spines at upper end of the emargination (the outer one apparently bifid for about two-thirds its length), apical spine somewhat long; joints of the front tarsi shorter than those on the other legs, first joint slightly longer than the next two taken together and about as long as the apical joint, joints two, three and four gradually shorter, hind tarsi with the first joint slightly longer than the apical joint, other joints shorter, claws distinctly but shortly pectinate; hind tibiæ, with spines similar to those on the middle tibiæ, on the outer side. Length $4.5 \mathrm{~mm}$.

Type. Ensenada, Puerto Rico, June 17 to 19, collected by Dr. F. E. Lutz, on the side hill back of Canary Cottage, under stones, in a field containing numerous cacti. In American Museum of Natural History. One paratype.Soledad, Cienfuegos, Cuba, October 26, collected by P. J. Darlington. In Museum of Comparative Zoölogy. Two paratypes.-Cayamas, Cuba, June 6, collected by E. A. Schwarz and Porto Rico, with no definite locality, collected by George N. Wolcott. In United States National Museum.

Remarks. This new species resembles Aephnidius (= Masoreus) piceolus Chaudoir, and believing that it might possibly be that species I failed to describe it in the recent paper on "New Species of Carabidæ from Puerto Rico" Amer. Mus. Novitates. No. 686. Since these descriptions appeared a specimen of this species from Cuba was submitted by Dr. P. J. Darlington to Mr. René Oberthür for comparison with the Chaudoir type.

The reply from Mr. Oberthür stated the Cuban specimen was not Chaudoir's species. The West Indian species differs in having the antennæ and legs stouter than the true piceolus (although still slender) and probably differs in other ways.

The paratype from Cayamas, Cuba, is somewhat brownish black in color, possibly due to being collected before the coloring had fully developed. 

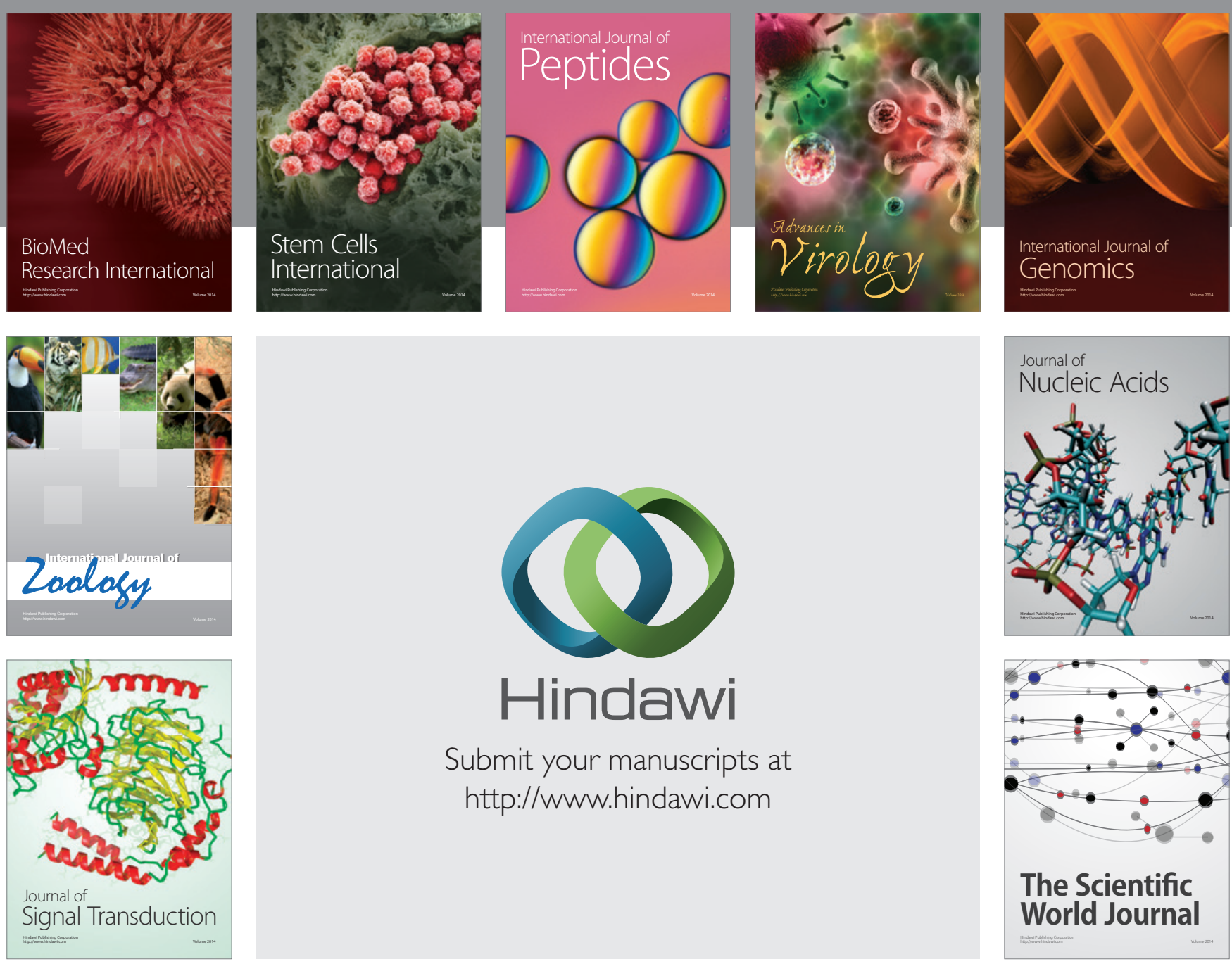

Submit your manuscripts at

http://www.hindawi.com
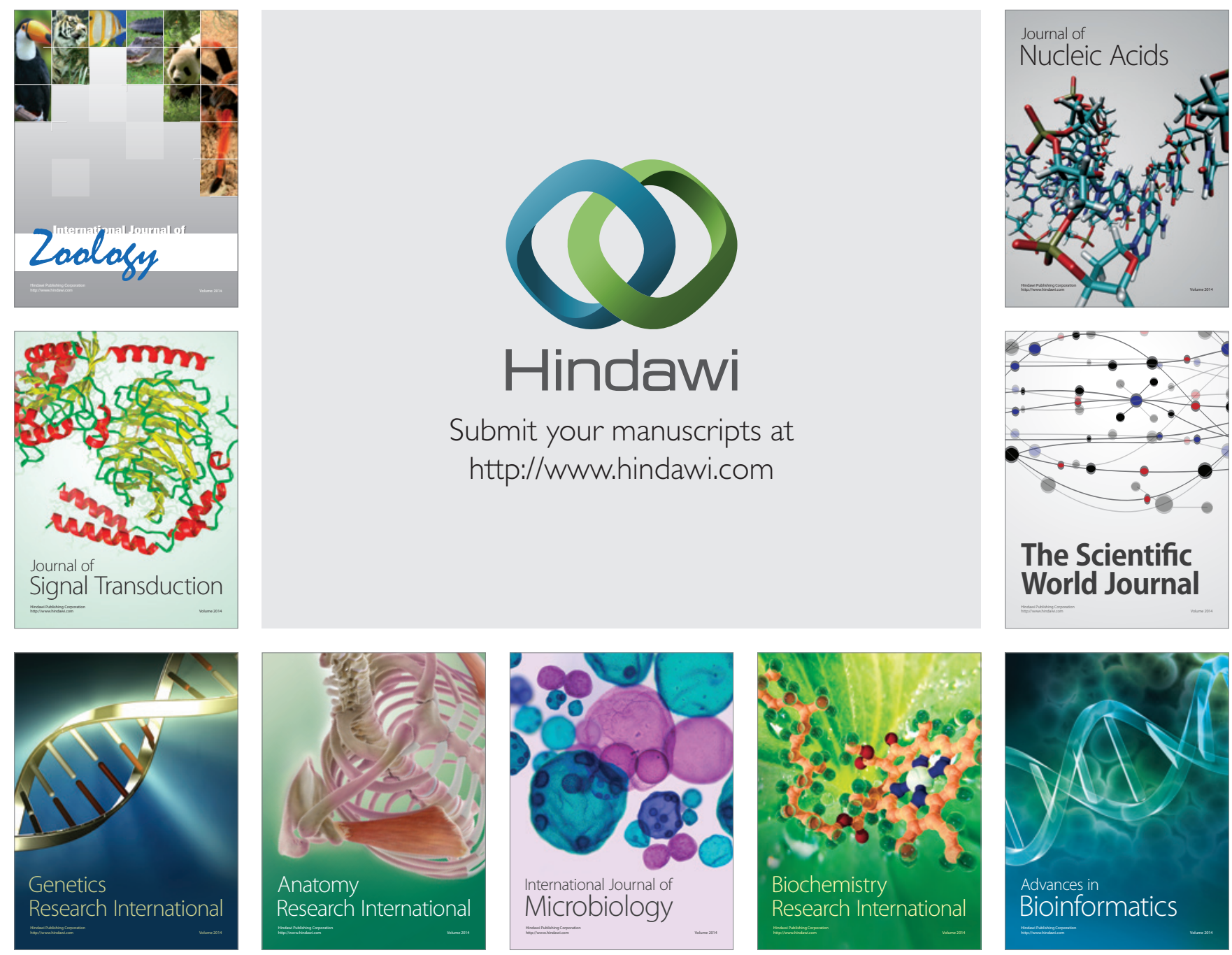

The Scientific World Journal
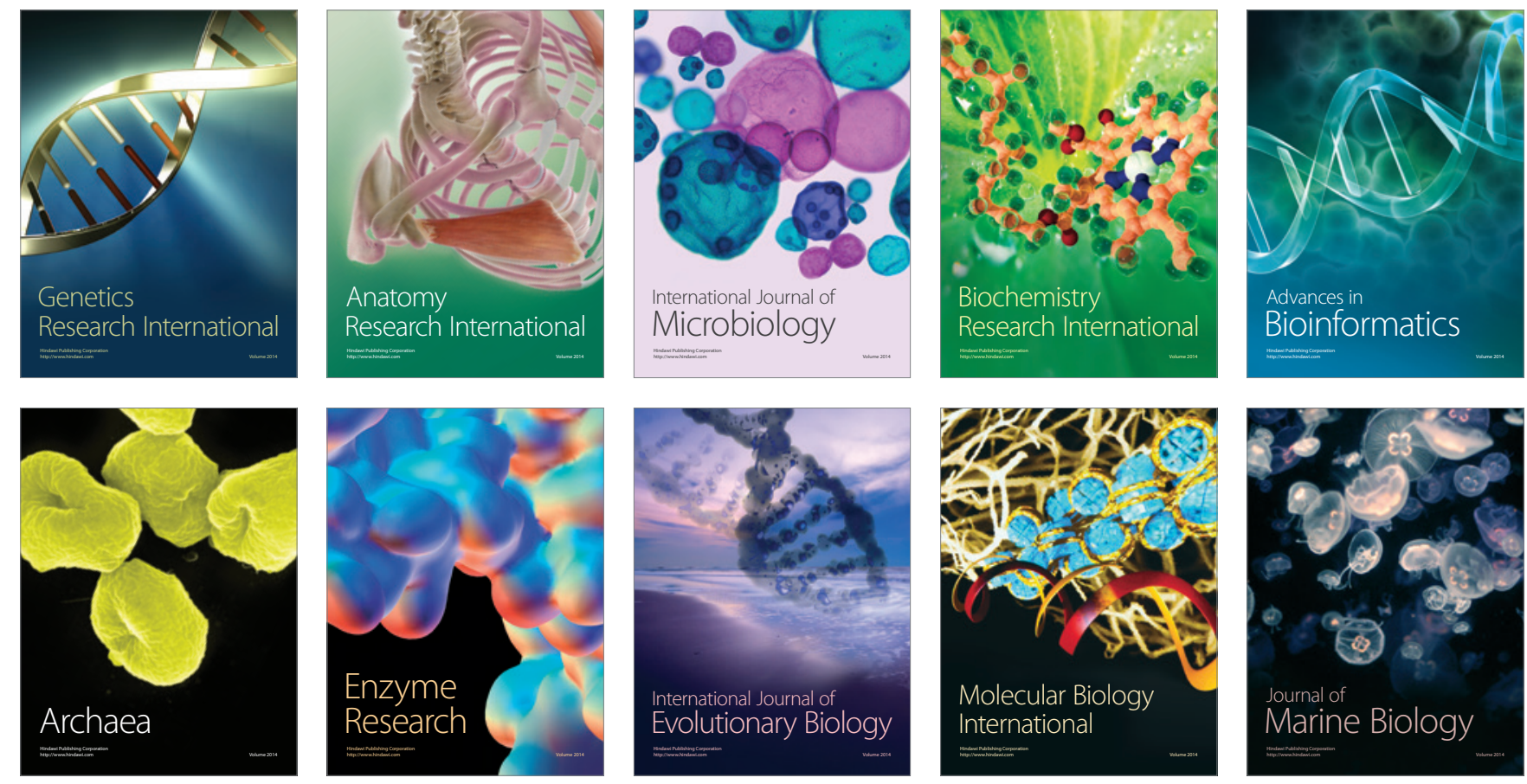